\title{
Review
}

\section{Awakening to Race: Individualism and Social Consciousness in America}

\author{
Jack Turner \\ University of Chicago Press, Chicago, 2012, 199pp., \\ ISBN: 9780226817125
}

Contemporary Political Theory (2017) 16, 578-584. doi:10.1057/s41296-017-0089-z; advance online publication 27 March 2017

In his last sermon, "Remaining Awake Through a Great Revolution," Martin Luther King, Jr. sounded an alarm intended to rouse his audience from a perilous obliviousness. Like Rip Van Winkle in Washington Irving's myth, King warned his listeners that they risked missing a world historical transformation. Unlike Rip, however, King's America was not comatose, nor was it simply lethargic or anesthetized by a single dogmatic slumber. American denial of its interconnectedness was part of a failure to see the collusion between race, class, and nation across time and space. Its people were haplessly marching into a future that they did not recognize as such and to which they refused to adapt. Ultimately, King's concern was not that Americans were merely asleep. Politically, they were sleepwalking.

The fact that too many are still sleepwalking well into the second decade of the twenty-first century is the occasion for Jack Turner's Awakening to Race: Individualism and Social Consciousness in America. Turner's critique of America's racial somnambulism ends with King and begins with the celebration of postracialism inaugurated with President Obama. Obama's ascent has given many license to adopt a posture of "no more excuses" in response to black suffering and racial inequality (p. 1), a recourse to self-uplift that King referred to as the "bootstraps philosophy" (p. 122). With so many examples of blacks in high places, those who invoke the significance of race need to quit complaining, and instead learn deal with people "as individuals." By extension of this logic, explanations for racial inequality should now be figured in terms of personal responsibility and not blamed on societal forces like racism. Such turns of thought, Turner argues, have effectively given individualism a bad name; "reflecting a narrow understanding of the philosophical tradition of American individualism" and an "impoverished sense of what democratic individualist thinkers such as Ralph Waldo Emerson, Henry David Thoreau, Frederick Douglass, Ralph Ellison and James Baldwin have said about personal responsibility and American democracy" (pp. 1-2).

(C) 2017 Macmillan Publishers Ltd. 1470-8914 Contemporary Political Theory Vol. 16, 4, 578-584 www.palgrave.com/journals 
Turner's inclusion and analysis of these thinkers is one of the book's core contributions; it takes seriously voices that challenge the prevailing (whitecentered) understandings of American individualism. Conjoining Thoreau's "moral obligation to throw off sleep" with Baldwin's insistence that self-awareness entails a painful confrontation with a reality which would otherwise remain disavowed, Turner contends that an encounter with race is a crucial component of any individualism worthy of its name (pp. 2-3). Authentic self-knowledge is unavailable to those who choose to remain unconscious of the others who make up their ethical and political universe. Equally important is the obvious performative contradiction at play when whites celebrate the virtues of their selfreliance and self-fashioning while simultaneously being hideously dependent upon non-whites for their privilege - and even their very identities as individuals. Turner inscribes his project within a horizon, writing: "This book does not conclusively answer the question of why so many white Americans fail to acknowledge racial injustice. Instead, it analyzes how this failure of acknowledgement constitutes a failure of democratic individualist virtue" (p. 7).

Existing versions of individualism not only tend to be rigidly atomistic, Turner argues, they're also insufficiently democratic. A democratic individual is open to reversing positions with others, adheres to the hypothetical reciprocity of the golden rule, and courts a "free and adventurous life" but not at the expense of those others, since to do so "would make his life less his own" (p. 8). The foregoing formulation is indebted to George Kateb, with whom Turner parts company in order to address Kateb's neglect of “African American democratic individualists most especially Douglass, Ellison and Baldwin" (p. 9). In the American context, it stands to reason that sober reflection on individualism demands that the philosophical problem of the one and the many engages the political and theoretical issues bequeathed by the nation's tortured racial history. Consequently, for Turner: "Awakening to race requires asking oneself, How has the history of white supremacy in the West affected me? What advantages have I derived from it? What burdens has it imposed on me? How might I free myself of it?" (p. 10).

Setting out to work "at the intersection of the history of American political thought and Democratic theory" (p. 12), the chapters unfold with a reading of Tocqueville's rendering of atomistic individualism as implicated in a withdrawal from civic life and an overblown sense of one's capacities (pp. 15-16, 18-25). An exaggerated sense of self-sufficiency is leveraged upon the individualist's disavowal of the social structures upon which he is dependent - such as white supremacy and male domination. Hypocritically, the white male requires the domestic labor of women and the forced servitude of blacks for his sense of "absolute independence" and belief that he is master of his own destiny (p. 24). The result, pace Tocqueville, condemns the atomistic individualist to a "selfdeluded moral failure" (p. 16). Nevertheless, Turner argues, such failure may be 
fate of "the atomistic individualist, it need not be the fate of the democratic individualist" (p. 16), a contention that prompts his turn to Emerson.

In Emerson, Turner locates a fusion of an ethics of self-reliance with that of noncomplicity. Acknowledging that Emerson never wrote a "sustained treatise" on the relationship between the two, Turner finds in Emerson's anti-slavery writings a firm belief in their compatibility (p. 28). Rather than view Emerson's anti-slavery activity as a departure from self-reliance, Turner contends that "moral selfexamination, avoiding complicity and political action are essential to self-reliance" (p. 29). By amplifying how the theme of complicity hovers in the background of Emerson's work, readers get a strong sense of how one race living in parasitic relationship with another - either directly or indirectly - is clearly anathema to selfreliance. Likewise, intellectual self-reliance cannot be achieved by anyone who participates in the kind of self-delusion that would conveniently justify slavery and exploitation in the first place (pp. 29-35). Exploitation "indebts the exploiter to the exploited, compromising the exploiter's autonomy" (p. 36). Thus, Turner locates in Emerson what he calls the nonexploitation obligation of democratic individualism (p. 45).

The upshot is a portrait of Emerson as more political insofar as his anti-slavery writings are not divorced from his broader intellectual pursuits (p. 40). Turner's Emerson avows the "inevitable necessity" that we need others' assistance, but that we "liquidate our debts through reciprocity" by helping others in turn (p. 37). It follows that the democratic individualist also has a duty to participate in a common effort to secure the material conditions required for self-reliance. Drawing upon Frederick Douglass, Turner calls this the democratic egalitarian obligation (pp. 45-63). Douglass's work allows Turner to amplify how the historical legacy of slavery left African Americans without the economic resources for self-uplift. Douglass's stance, he argues, is not incompatible with requiring individuals to provide for themselves and their families. "The job of liberal democratic government is to ensure not only freedom from tyranny and anarchy, but also freedom from helplessness" (p. 49). For Douglass, "[f]reedom without means of subsistence is meaningless" (p. 56). Readers see in Douglass a deep respect for private property as well as policy proposals that were neither confiscatory toward Confederates nor giveaways to freedmen. Turner contends that the complexity of Douglass's views is especially useful in helping contemporary audiences resist the false choice between self-help and structural reform, since the latter should enable the former (p. 63).

In the two subsequent chapters, Turner takes up the work of Ralph Ellison and James Baldwin to expand upon the democratic individualist imperative to awaken to race. In important ways, both authors provide a crucial intervention into prevailing modes of seeing - or, more accurately, not seeing - reality with respect to race. Thinkers such as Emerson, Thoreau, and Whitman were regarded as progressive for their time but still held fast to the belief in "Anglo Saxon 
superiority and abstracted their democratic visions of individuality primarily from the lives of whites" (p. 66). Through his analysis of Ellison's essays, plays, and his magnum opus, Invisible Man, Turner deftly renders what he calls "democratic individuality in black" (p. 68). The trials and travails of Invisible Man's nameless protagonist allow Turner to draw the reader into a conjunctive space where politics and individual moral responsibility are dramatized. Here invisibility is not simply a condition of Ellison's protagonist but refers to "the American individual generally" (p. 69). Since our self-knowledge is occluded by our burial of historical truths, Ellison's narrator fittingly illuminates the New York underground in one of the book's defining scenes. In attempting to, as Ellison put it, "return to the mood of personal moral responsibility for democracy" through a "keener sense of reality," he "provides Americans with the imaginative equipment they need to escape racialized social outlooks and see the world from the perspective of racial others" (pp. 72-73). Ellison affords this perspective through literary metaphor but also via the disavowed history of America's racial hybridity - what James Baldwin refers to as the "blood relationship" between blacks and whites (p. 82).

It is Baldwin who receives the place of highest honor in the book. In Turner's view, he "personifies 'awakening to race"” (p. 89). Baldwin illustrates American individuality's multiple sources (p. 90), the demand for artful self-cultivation under duress (pp. 92, 109), and the fierce independence of intellect that develops from one's attachments, interlocutors, and support networks (p. 91). Baldwin argues ferociously against the compulsive disavowal of white supremacy which he terms "innocence," and keeps company with Ellison in the need to trust and affirm one's experience in the face of chauvinistic powers that would dismiss the experiences of non-whites as meaningless (p. 109). For Turner, Baldwin does not "reject liberalism per se, but...the imperfect ways that Americans enact it" (p. 94). Liberalism does not lack "competing myths," however, and these need to be interrogated through a sharp confrontation with one's desires, attachments, and enfleshed dispositions (p. 94).

In his reading of Baldwin as a theorist of democratic reconstitution, Turner offers an ambitious "thought experiment" with respect to what such a reconstitution might entail in practice (p. 100). Experimentation and attention to logical entailment are called for, in part because Baldwin does not directly confront questions of whether, for example, the democratic state should "ensure something approaching absolute social and material equality" (p. 103). Yet Turner does see Baldwin endorsing a renunciation of unfair privelage and providing broader ethical guideposts for democratic conversation. Agonistic love and brutal frankness between differently situated peoples are prerequisites to becoming co-creators of each other's consciousness (p. 105). These qualities align with Baldwin's emphasis on confronting the past as key to meaningful self-creation, as opposed to fantasies of self-invention unconditioned by history. In sum, Turner identifies four critical interventions of African American individualism which contribute to a revision of 
American individualism: a socioeconomic realism that eschews the fiction that everyone starts off with adequate resources for self-uplift, a sensitivity to the dialectics of identity and difference, a fortification of historical consciousness, and the virtue of relinquishing unjustifiable advantage (pp. 113-115).

Much of the force of Turner's argument comes from his ability to deploy his chosen authors to expose the hypocrisy of prevailing fictions around American individualism. The perils of the all-too-common blind extrapolation of white experiences into a supposedly comprehensive theoretical framework or political ethos are sharply critiqued in these pages. On one level, this makes Turner's study especially revelatory for audiences steeped in the rhetorical tradition of atomistic American individualism and "the bootstraps philosophy" that simply cannot be sustained against the authors and evidence marshaled in Awakening to Race. Furthermore, the book's lucidity makes its argumentative power available to undergraduate audiences and general readers unfamiliar with individualism in black. If these were the book's only contributions, it would stand as an admirable achievement. On another level, I think that the study can also be read as laying the groundwork for a broader contestation about the democratic limits and possibilities of liberalism with respect to race.

Turner writes that he sees "democratic individualism as basically synonymous with what is commonly called liberal individualism." He explains:

I see liberalism and democracy as mutually constitutive.... Liberalism does not necessarily imply commitment to unregulated markets and minimalist government...Liberalism should not be confused with neoliberalism. Liberalism implies democracy because the right to lead free, self-determining lives includes the right to participate in political decisions. (p. 134)

Turner holds that "democracy implies liberalism" because democratic rule of the people does (or should) consist of "each and every individual in a given society, and the exclusion of any one of them is undemocratic." Since "the right of individuals to self-determination" is what gives "the idea that the people should rule" its "normative force," "[r]adical democrats are thus far more liberal individualist than they admit" (p.134). Yet in an effort to "find common ground with radical democrats" skeptical of liberalism, Turner opts to use the term "democratic individualism ... and save for another day the debate over whether the foundations of democracy are inescapably liberal" (p. 134).

Leaving aside the ancient Greek foundations of democracy, Turner's study is still relevant to the questionable status of modern liberal ideals and practices whose long shadows stretch to the present day. For instance, while Turner holds that liberalism does not necessarily entail unregulated markets, he also acknowledges that Baldwin is highly skeptical of property, whether it appears as a right to selfownership or external things (pp. 98-99). As Turner reads him, Baldwin's logic can nevertheless be extended to the point of endorsing the divestiture of property as part 
of a project of democratic reconstitution (pp. 101-103, 113). Still, individual property rights are integral to liberalism. Moreover, feminist, indigenous, decolonial, and critical race theorists rightly remind us that it is exceedingly difficult to unhinge the door opening onto liberal freedom from the various kinds of human property upon which that passage has historically been framed. Hence it remains the prerogative of power to dispose of those formerly regarded as property but still stigmatized by race.

Turner states that his intention is not to explain why whites are so willfully ignorant when it comes to race. That caveat notwithstanding, it is to his credit that the book's textual exegesis disrupts the totalizing projections of what is commonly referred to as the white gaze - a phrase that sometimes functions as a genteel euphemism for white power's assumed prerogative to define, aggregate, objectify, and dehumanize its others. The intellectual laziness and vapidity afforded by white privilege proffers a narcotic indifference to even the most brilliant displays of nonwhite individuality. (It is this tendency that I take Ani DiFranco to be mocking when she writes: "I know so many white people, I mean, where do I start? The trouble with white people is you can't tell them apart.") Baldwin addresses that racialized phenomenology by indicating that whiteness is not just about phenotype but a "state of mind." Such remainders and tensions give me pause about the ultimate compatibility of the liberal tradition and the project of democratic reconstitution that Turner so admirably affirms.

The book's emphasis on the needed work of reconstituting democracy by awakening to race invites us into a deeper meditation on both the pejorative and aspirational aspects of what it means to dream politically. For sure, dreaming has negative connotations deployed to deride those overtaken by the anesthesia of slumber like Rip, those who daydream on the job, or unrealistic utopians dismissed as mere dreamers. From a different angle, post-Freudian heirs of Lacan tend to regard dreams as psychological survival mechanisms, reading dreamscapes as standing in symbolically for things too dangerous to countenance in waking life. Politically, DREAMERS also refers to those seeking citizenship but often crudely gathered under the heading of "illegals." In an age when the message to such democratic aspirants is to "keep dreaming," Turner's book might be read as calling attention to a need to awaken to how dream deferral might function as an integral aspect of liberalism in contemporary practice, if not always in theory. Liberalism's repeated, undelivered promises that individual rights will come to people of color in some future time that has not yet arrived can make dreaming appear as a counsel of quiescence; a tool of power. King evinced such skepticism when he insisted that we wake up to the fact that justice deferred is justice denied.

As a measure of our liberal commitments, Turner invokes Baldwin's call to resist the false divide between principles and practice in order to evaluate our experiences, our desires, and our actions - all of which show how the "principles we avow often camouflage the practices we live by" (p. 94). Turner finds that 
"Baldwin invariably condemns liberals not liberalism" (p. 93), indicating that he "has not found a single instance in Baldwin's essays where he refers to liberalism as a doctrine or philosophy" (p. 94). Nevertheless, further on, he writes "American liberalism, according to Baldwin, is also bound up with a set of comforting myths" (p. 94). As to the former statement, Baldwin himself is not entirely helpful since it is not always clear whether he is referring to those who fancy themselves progressives on the left or if his target is the dutiful heirs of Enlightenment liberalism per se. With respect to the latter, I certainly concur that American liberalism is rife with mythology. But perhaps we also have to entertain the possibility that Baldwin is heralding a need to wake up to a dream state that is constitutive of liberalism itself.

Whereas Turner suspects that radical democrats are more liberal than they would admit, I wonder whether the book's argument makes Turner closer to radical democrats than he admits. The tensions in his reading of Baldwin make this question especially sailient. For Baldwin, the trouble is that the dream of white liberals is contrary to anything resembling individualism. White liberal "good will, from which we yet expect such power to transform us...leads only back to our forebears, whose assumption was that the black man, to become truly human and acceptable, must first become like us" (Baldwin, 1985, p. 78). By my lights, the passage calls into question the sufficiency of the resources available within liberalism for racial awakening. Suggesting that Baldwin is ultimately a sympathetic critic of liberalism, Turner quotes Baldwin's characterization of the dream of well-intentioned liberals who seek to "join hands and walk together into that dazzling future when there will be no white or black. This is the dream of all liberal men" (p. 94). Yet if one seeks from Baldwin an intimation that liberal dreamscapes might imperil transracial democracy-not least by their conflation of equality with sameness-one need look no further than how Baldwin completes that very sentence. As he puts it, the dream of a future where there is no white or black "is the dream of all liberal men, a dream not at all dishonorable, but, nevertheless, a dream" (Baldwin, 1985, p.78. Emphasis added).

\section{Reference}

Baldwin, J. (1985). The Price of the Ticket: Collected Nonfiction 1948-1985. New York: St. Martin's Press.

P. J. Brendese Johns Hopkins University, Baltimore, MD 21218, USA pbrende1@jhu.edu 